\title{
An application of multiple attribute group decision making in ranking investors' concerns: A case study of Tehran Stock Exchange
}

\author{
Amir Mohammadzadeh ${ }^{\mathrm{a}}$, Naser Hamidi ${ }^{\mathrm{b}^{*}}$, Sadegh Abedic ${ }^{\mathrm{c}}$ and Fehimeh Jabari ${ }^{\mathrm{d}}$
}

${ }^{a}$ Department of Management ,Islamic Azad University, Qazvin Beranch, Qazvin, Iran

${ }^{b}$ Department Management, Islamic Azad University, Qazvin Branch, Qazvin, Qazvin, Iran

${ }^{c}$ PhD Student, Department Management, Islamic Azad University, Qazvin Branch, Qazvin ,Iran

${ }^{d}$ Department of Management ,Allmeh Reffiae University, Qazvin, Iran

C H R O N I C L E

Article history:

Received October 9, 2012

Received in revised format

29 November 2012

Accepted 27 December 2012

Available online

January 32013

Keywords:

Borda method

Tehran Stock Exchange

Barriers

\section{A B S T R A C T}

During the past few years, stock exchange investors confront numerous problems in terms of legal, environmental issues, etc. In this paper, we present an empirical study to detect important issues as barriers for investment in Tehran Stock Exchange. The study has categorized the issues into two groups of real world and legal issues. Since there are different issues involved as major barriers, the study uses analytical hierarchy process to rank them. The study extracts 18 important factors, which influence investors' participation in Tehran Stock Exchange and using Borda method, prioritize them. The results of the survey indicate that in terms of real issues, Increase in quality of firms Financial Statement is number one priority followed by Increase stock exchange and agents' proficiency and electronic equipment, Unchangeable investment market rules and bounding organization managers to flow them and Strict supervision on agents' activities. In terms of legal issues, good supervision of provisions to force firms to reveal information correctly and restrict their secret bargaining is the most important factor followed by Using indirect investment guideline instead of direct investment, Increase in quality of firms' Financial Statement and Investors' training toward their rights.

\section{Introduction}

One of the most important issues in any economy is to direct people's saving into stock exchange in order to boost the economy. In fact, when people participate in investing through stock exchange, they contribute to global economy. In United States, over $70 \%$ of people's savings are held as investment on shares traded in stock market. However, in Iran, many people are unwilling to invest their savings in Tehran Stock Exchange and they prefer to direct their money into real-state, gold, etc. Therefore, it is important to learn more about the possible barriers or lack of motivation and plan for possible actions to remove them.

*Corresponding author.

E-mail addresses: nhamidi1344@gmail.com (N. Hamidi) 
During the past few years, there have been different studies associated with major issues surrounding Tehran Stock Exchange. VakilAlroaia et al. (2012), for instance, performed an empirical investigation on relationship between forward-backward factors on stock return, using Price-Earnings ratio $(\mathrm{P} / \mathrm{E})$ and stock fluctuation based on monthly time series pattern over the period 2006-2010. They described that the independent variables could influence on the research's dependent variable, which indicated that the impact of company's systematic risk and markets risk on companies' stock return were positive. Khodaei Valahzaghard and Salehi (2012) did another survey on the effect of the corporate governance characteristics and ownership on earnings quality in Iranian banking sector.

Sohrabi Araghi and Attari (2013) studied the impact of accruals and operating cash flows on users' decisions on financial statements for a case study of firms listed in Tehran Stock Exchange. They performed an investigation on the effect of accruals and operating cash flows in decisions of financial statement users for some companies whose shares were traded on Tehran stock exchange. They suggested that there was a different between accruals and operating cash flows data content in terms of various decision-making criteria. Nelson (2005) performed an empirical investigation on corporate governance practices, CEO characteristics and firm performance.

Panahian et al. (2008) investigated the relationship between discretionary accruals quality as well as innate accruals quality and portion of non-executive board of directors, concentration of ownership ratio and board size in Tehran Stock Exchange. They reported that an increase on non-executive members positively could impact on discretionary accruals quality and negatively influenced innate accruals quality. They also explained that concentration of ownership ratio positively impacted on discretionary accruals quality and negatively influenced on innate accruals quality. Based on their survey, size of board of directors negatively impacted discretionary accruals quality and positively impacted on innate accruals quality. Ştefănescu (2011) investigated the level of disclosure ensured by corporate governance codes in force in European Union member states and explained that common law regime could ensure the biggest level of transparency through corporate governance requirements.

\section{The proposed study}

This investigation is classified as descriptive, gauging since it seeks to solve problems, we can use the results practically, and it is counted as a functional investigation. Statistical society in this survey includes direct reference to expert investors, with regard to expertise indexes, in stock exchange. Regarding to undetermined investors in under evaluation society and lack of accessibility (for resources limitation), a sample of 30 people was selected. Standard levels were selected for each index in this method, at least M.A. education, at least 5 years' experience in stock exchange, at least 100 transactions in stock exchange and people who were available for consecutive study and four periods questionnaire distributions. The option score in each index must not be lower than the standard level for acceptance. The researcher ' questionnaire is the used tool in this survey. At the first stage of questionnaire, Likert scale factoring analysis has been used for determining investors' problems. Second, the effective factors of investors' problems creation and their effect coefficients in real and legal issues were determined by Likert scale factoring analysis. Third, pair comparisons were used and problem solving strategies prioritizing were practiced via Borda mathematical method in the second section of the third stage.

\section{Survey findings after analysis data}

Current survey findings include types of information as well as determination of investors' problems in stock exchange on real and legal sections are shown in Table 1. 
Table1

Definition investors' problems in stock exchange

\begin{tabular}{lcc}
\hline Factors & Legal section* & Real section* \\
\hline Lack of professional business man who experience market's fluctuations repeatedly & 45.55 & 77.777 \\
Lack of stock holding culture among common people & 26.66 & 92.55 \\
Deficiency of transparent information in some firms & 36.66 & 92.5 \\
Deficiency of expert forces in capitalization consulting & 24.44 & 85.111 \\
Violation of stockholders' rights except in some firms' main stockholders & 25.555 & 55.555 \\
Existence of classified information in market & 85.11 & 56.66 \\
Lack of efficient educational places in fundamental analysis level & 36.66 & 62.22 \\
Lack of derivative instruments in market & 91.1 & 50.12 \\
Lack of suitable analyzer in market & 34.4 & 84.4 \\
Inadequacy of capitalization consulting institutions & 92.22 & 70 \\
\hline
\end{tabular}

Inadequacy of capitalization consulting institutions

* Effectiveness degree out of 100

According to the results of Table 1, all 10 problems were effective as real issues and lack of derivative instruments in market, Inadequacy of capitalization consulting institutions and Existence of classified information in market were altogether effective as legal issues. Determination of effective factors in cause problems and their influence coefficients on legal sections are shown in Tables 2 .

\section{Table 2}

Determination of effective factors in cause problems in legal section

\begin{tabular}{|c|c|c|c|c|}
\hline Legal investors problems & Effective factors in causing problem & Samples** & legal section* & real section* \\
\hline \multirow{3}{*}{$\begin{array}{l}\text { Existence of classified } \\
\text { information in market }\end{array}$} & Lack of efficiency in capital market & 16 & 59.98 & 79.21 \\
\hline & $\begin{array}{l}\text { Excessive demand of stock exchanges' } \\
\text { managers }\end{array}$ & 16 & 74.39 & 61.36 \\
\hline & Exclusiveness of stock market & 15 & 45.6 & 58.56 \\
\hline \multirow[b]{2}{*}{$\begin{array}{l}\text { Inadequacy of capitalization } \\
\text { consulting institutions }\end{array}$} & Immaturity of Security exchange & 17 & 34.45 & 81.11 \\
\hline & $\begin{array}{l}\text { Lack of equilibrium between industry and } \\
\text { university }\end{array}$ & 16 & 55 & 78.32 \\
\hline $\begin{array}{l}\text { Inadequacy of capitalization } \\
\text { consulting institutions }\end{array}$ & $\begin{array}{l}\text { Lack of defined academic courses relating } \\
\text { capitalization consulting }\end{array}$ & 18 & 50.26 & 77.15 \\
\hline \multirow{2}{*}{$\begin{array}{l}\text { Lack of derivative instruments } \\
\text { in market }\end{array}$} & $\begin{array}{l}\text { Lack of literature about this instrument and } \\
\text { its substructure }\end{array}$ & 19 & 36.62 & 71.58 \\
\hline & $\begin{array}{l}\text { Lack of cognition toward derivative } \\
\text { instruments }\end{array}$ & 19 & 54.52 & 80.1 \\
\hline
\end{tabular}

*Effectiveness degree from $100, * * \mathrm{~N}=30$

Analytical hierarchy process (AHP) (Saaty, 1992) is one of the most popular multiple criteria decision making problems. The proposed model of this paper uses AHP to rank different alternatives. We have considered different criteria including Modeling, Preferential, Judgment and we have calculated relative weights and calculated the consistency ratio. Table 3 shows the comparison among various decision options accomplish base on pair comparison among indexes.

\section{Table 3}

Preferential Matrix for each problem weights in real section

\begin{tabular}{|c|c|c|c|c|c|c|c|}
\hline & 1 & 2 & 3 & 4 & 5 & 6 & 7 \\
\hline $\begin{array}{l}\text { Lack of stock holding culture among } \\
\text { common people (1) }\end{array}$ & 1 & 2.83772 & 0.48141 & 0.61225 & 0.64123 & 1.85949 & 0.47464 \\
\hline Lack of professional dealers(2) & 0.35223 & 1 & 0.385974 & 0.43146 & 0.42767 & 0.85361 & 0.4158 \\
\hline $\begin{array}{l}\text { Shortage in providing transparent } \\
\text { information in some firms ( } 3 \text { ) }\end{array}$ & 2.07589 & 2.59048 & 1 & 1.251033 & 1.2784 & 2.31348063 & 1.21553 \\
\hline $\begin{array}{l}\text { Lack of professionals for capitalization } \\
\text { consulting (4) }\end{array}$ & 1.63197 & 2.31767 & 0.93424 & 1 & 1.01121965 & 2.08112013 & 1.0533 \\
\hline $\begin{array}{l}\text { Violation of stockholders' rights except } \\
\text { in case of main shareholders (5) }\end{array}$ & 1.55890 & 2.337996 & 0.67591987 & 0.98885536 & 1 & 1.92533 & 1.06929 \\
\hline $\begin{array}{l}\text { Lack of efficient educational places in } \\
\text { fundamental analysis level (6) }\end{array}$ & 0.53768 & 1.13153 & 0.37353 & 0.48050 & 0.51939 & 1 & 0.51079 \\
\hline Lack of suitable analyzer in market (7) & 2.10529 & 2.27896 & 0.897696 & 0.9398 & 0.800155 & 1.95776 & 1 \\
\hline Sum & 9.26197 & 14.494 & 4.74878 & 5.703983 & 5.67813 & 11.9907 & 5.739498 \\
\hline
\end{tabular}

\footnotetext{
*Analysis by AHP approach, $\mathrm{CI}=0.01165, \mathrm{CR}=0.0088$
} 
The results of Table 3 reveal that consistency ratio is within an acceptable limit of 0.1 , which means we can rely on our findings. The results indicate that Shortage in providing transparent information in some firms is the most important factor, followed by Lack of suitable analyzer in market, Lack of professionals for capitalization consulting, Violation of stockholders' rights except in case of main stockholders. In addition, Lack of stock holding culture among common people, Lack of efficient educational places in fundamental analysis level and Lack of professional dealers in market are in the lower priorities.

\section{Table 4}

Determination of effective factors in cause problems in real section

\begin{tabular}{|c|c|c|c|c|c|}
\hline Real investors problems & Effective factors in causing problem & Samples* & $\begin{array}{c}\text { legal } \\
\text { section* }\end{array}$ & $\begin{array}{c}\text { real } \\
\text { section* }\end{array}$ & AHP rank \\
\hline \multirow{4}{*}{$\begin{array}{l}\text { Lack of suitable analyzer in } \\
\text { market }\end{array}$} & Lack of analyzers' absolute commitment & 15 & 19.91 & 84.61 & 0.387119 \\
\hline & Non application of financial management & 14 & 48.86 & 66.25 & 0.280739 \\
\hline & Lack of agents' continues evaluation & 14 & 19.90 & 66.21 & 0.180012 \\
\hline & Lack of scientific awareness in agents & 14 & 22 & 81.36 & 0.152129 \\
\hline \multirow{3}{*}{$\begin{array}{l}\text { Lack of efficient educational } \\
\text { places in fundamental analysis } \\
\text { level }\end{array}$} & $\begin{array}{l}\text { Government play down of monetary and } \\
\text { financial market functions }\end{array}$ & 17 & 14.41 & 59.99 & 0.44 \\
\hline & Lack of timely and proper budget allocation & 17 & 36.98 & 60 & 0.133 \\
\hline & Lack of knowledge about Securities industry & 14 & 45 & 85.21 & 0.426349 \\
\hline \multirow[b]{2}{*}{$\begin{array}{l}\text { Violation of stockholders' } \\
\text { rights except in case of main } \\
\text { stockholders shareholders }\end{array}$} & Lack of proper legal structure & 12 & 20.11 & 58 & \multirow{2}{*}{$\begin{array}{l}0.333 \\
0.667\end{array}$} \\
\hline & $\begin{array}{l}\text { Using power and take stock exchange control } \\
\text { by a few of shareholders }\end{array}$ & 12 & 16.16 & 59 & \\
\hline \multirow{2}{*}{$\begin{array}{l}\text { Lack of professionals for } \\
\text { capitalization consulting }\end{array}$} & Lack of investment development in securities & 12 & 36.68 & 78.31 & 0.357 \\
\hline & lack of expert educational places for training & 17 & 40 & 80 & 0.643 \\
\hline \multirow{2}{*}{$\begin{array}{l}\text { Shortage in providing } \\
\text { transparent information in }\end{array}$} & Lack of proper legal structures & 17 & 25.32 & 78.12 & 0.55789 \\
\hline & Lack of proper auditing structures & 16 & 36.69 & 69.19 & 0.44211 \\
\hline \multirow{3}{*}{$\begin{array}{l}\text { Lack of professional dealers } \\
\text { who experience market's } \\
\text { fluctuations repeatedly }\end{array}$} & Deficiency of all stock exchange transactions & 19 & 30.13 & 60.11 & 0.21401 \\
\hline & Inexperience dealers & 21 & 18.89 & 84.14 & 0.16801 \\
\hline & Lack of investment incitement because of & 15 & 17.68 & 83.13 & 0.61798 \\
\hline \multirow{3}{*}{$\begin{array}{l}\text { Lack of stock holding culture } \\
\text { among common people }\end{array}$} & Lack of public training & 18 & 39 & 59.91 & 0.33916 \\
\hline & Immaturity of investment industry & 16 & 25.84 & 68.54 & 0.30534 \\
\hline & Minimizing stock exchange advantages & 17 & 24.41 & 70 & 0.3555 \\
\hline
\end{tabular}

Table 5 shows details of the implementation of our AHP method for ranking various items associated with legal issues.

\section{Table 5}

The results of prioritizing legal issues

\begin{tabular}{|c|c|c|c|c|c|}
\hline Priority & Factor & Weight & Effective factors in causing problem & Final weight & Priority \\
\hline \multirow{3}{*}{1} & \multirow{3}{*}{$\begin{array}{l}\text { Existence of } \\
\text { classified } \\
\text { information in } \\
\text { market }\end{array}$} & \multirow{3}{*}{0.7704} & $\begin{array}{l}\text { Lack of defined academic courses relating capitalization } \\
\text { consulting }\end{array}$ & 0.698832 & 1 \\
\hline & & & Lack of equilibrium between industry and university & 0.159348 & 2 \\
\hline & & & Immaturity of Security exchange & 0.141821 & 3 \\
\hline \multirow[t]{2}{*}{2} & \multirow{2}{*}{$\begin{array}{l}\text { Lack of derivative } \\
\text { instruments in } \\
\text { market }\end{array}$} & \multirow[t]{2}{*}{0.1386} & $\begin{array}{l}\text { Existence of records on derivative instruments in market } \\
\text { and its substructures }\end{array}$ & 0.6341 & 1 \\
\hline & & & Lack of cognition toward derivative instruments & 0.363 & 2 \\
\hline \multirow{3}{*}{3} & \multirow{3}{*}{$\begin{array}{l}\text { Deficiency of } \\
\text { investment } \\
\text { consulting } \\
\text { institutions }\end{array}$} & \multirow{3}{*}{0.0910} & Non application of capital market & 0.652135 & 1 \\
\hline & & & $\begin{array}{l}\text { Exclusiveness of stock market toward a few of share } \\
\text { holders }\end{array}$ & 0.19619 & 2 \\
\hline & & & Excessive demand of stock exchanges' managers & 0.151675 & 3 \\
\hline
\end{tabular}

Based on the results of the Table 4 and Table 5, we can summarize the following strategies for possible actions to reduce investors' problems summarized in Table 6. Borda is a well-known mathematical method for group decision making in evaluation and selection indexes in real-world problems and the proposed model of this paper uses this mathematical model for ranking barriers. 
Table 6

Suggested strategies for decreasing stock exchange investors' problems

\begin{tabular}{lc}
\hline Strategy & Rank \\
\hline Promoting investment culture among common people via setting up educational boards & 1 \\
\hline Carrying on expert and complementary educational programs & 2 \\
\hline Increase stock exchange and agents' proficiency and electronic equipment & 3 \\
\hline Strict supervision on agents' activities & 4 \\
\hline Increase in quality of firms financial statement & 5 \\
\hline Unchangeable investment market rules and bounding organization managers to flow them & 6 \\
\hline Supervision on right execute of provisions to force firms to disclose information properly and restrict their secret bargaining & 7 \\
\hline Focus on monetary and financial market functions in economy & 8 \\
Increase auditors' proficiency & 9 \\
Bounding agents to have analyzing license & 10 \\
Using indirect investment guideline instead of direct investment & 11 \\
Offering derivative instruments in investment market & 12 \\
\hline Development of common investment fund in counties & 13 \\
Agents continues evaluating & 14 \\
Using collective voting system & 15 \\
Timely and proper budget allocation & 16 \\
Analyzers' absolute commitment and interest creating agents and & 17 \\
Investors' training toward their rights & 18 \\
\hline
\end{tabular}

Ranking effective strategies to decrease real and legal problems using Borda approach (Hamidi et al., 2012) in real section are demonstrated in Eqs. (1-4) as follows,

(Borda Model) $\max (Z)=\sum_{i=1}^{18} \sum_{t=1}^{18} q_{i, t} \cdot h_{i, t}$

subject to

$\begin{array}{ll}\sum_{i=1}^{18} h_{i j}=1, & j=1, \ldots ., 18 \\ \sum_{j=1}^{18} h_{i j}=1, & i=1, \ldots, 18 \\ h_{i j}=(0,1) & \end{array}$

The proposed Borda model presented from Eq. (1) to Eq. (4) is a mixed integer programming, which could be solved for real and legal parts, separately. Table 7 demonstrates details of our findings.

Table 7

Selection Ranking Possible Strategy in real and legal section

\begin{tabular}{lcc} 
& $\begin{array}{c}\text { Real } \\
\text { Section }\end{array}$ & $\begin{array}{c}\text { Legal } \\
\text { Section }\end{array}$ \\
\hline Increase in quality of firms Financial Statement & 3 \\
\hline Increase stock exchange and agents' proficiency and electronic equipment & 2 & 7 \\
Unchangeable investment market rules and bounding organization managers to flow them & 8 & 11 \\
Strict supervision on agents' activities & 4 & 10 \\
Promoting investment culture among common people via setting up educational boards & 5 & 9 \\
Carrying on expert and complementary educational programs & 6 & 7 \\
Government's focus on monetary and financial market functions & 13 \\
Analyzers' absolute commitment and interest creating agents and & 14 \\
Supervision on right execute of provisions to force firms on disclosing information properly and restrict their & 8 & 1 \\
secret bargaining & 9 & 1 \\
Using collective voting system & 10 & 17 \\
Investors' training toward their rights & 11 \\
Increase auditors' proficiency & 4 \\
Bounding agents to have analyzing license & 12 \\
Agents continues evaluating & 13 \\
Offering derivative instruments in investment market & 12 \\
Using indirect investment guideline instead of direct investment & 14 & 15 \\
Development of common investment fund & 5 \\
Timely and proper budget allocation & 15 & 5 \\
\hline
\end{tabular}


As we can observe from the results of Table 7, in terms of real issues, Increase in quality of firms Financial Statement is number one priority followed by Increase stock exchange and agents' proficiency and electronic equipment, Unchangeable investment market rules and bounding organization managers to flow them and Strict supervision on agents' activities. In terms of legal issues, good supervision of provisions to force firms to reveal information correctly and restrict their secret bargaining is the most important factor followed by Using indirect investment guideline instead of direct investment, Increase in quality of firms' Financial Statement and Investors' training toward their rights.

\section{Conclusion}

In this paper, we have performed an empirical investigation to find important issues as barriers for investment in Tehran Stock Exchange. The study has categorized the issues into two groups of realworld and legal issues. Since there are different issues involved as major barriers, the study has implemented AHP to prioritize them. We have also extracted 18 important factors, which could influence investors' participation in Tehran Stock Exchange and using Borda method, we have prioritized them. The results of our survey have concluded that in terms of real issues, Increase in quality of firms Financial Statement is number one priority followed by Increase stock exchange and agents' proficiency and electronic equipment, Unchangeable investment market rules and bounding organization managers to flow them and Strict supervision on agents' activities. In terms of legal issues, good supervision of provisions to force firms to reveal information correctly and restrict their secret bargaining is the most important factor followed by Using indirect investment guideline instead of direct investment, Increase in quality of firms' Financial Statement and Investors' training toward their rights.

\section{References}

Hamidi, N., Yousefi, P., Rahimi, A., \& Jabari, F. (2012). A hybrid of Borda and DEMTEL for productivity improvement. Management Science Letters, 2(8), 2757-2764.

Khodaei Valahzaghard, M., \& Salehi, A. (2012). Impact of the corporate governance characteristics and ownership on earnings quality of the Islamic private banks in Iran. Management Science Letters, 2(7), 2607-2614.

Panahian, H., Ghodrati, H., \& Nazari, M. (2012). Innate and discretionary accruals quality and corporate governance: A case study of Tehran Stock Exchange. Management Science Letters, 2(8), 3023-3030.

Nelson, J. (2005). Corporate governance practices, CEO characteristics and firm performance. Journal of Corporate Finance, 11(1-2). 197-228.

Saaty, T. L. (1992). How to make a decision: the analytic hierarchy process. European Journal of Operational Research, 48, 9-26.

Sohrabi Araghi, M., \& Attari, S. (2013). Comparing the role of accruals and operating cash flows on users' decisions on financial statements: A case study of Tehran Stock Exchange. Management Science Letters, 3(1), 97-106.

Ştefănescu, C.A. (2011). Disclosure and transparency in corporate governance codes - comparative analysis with prior literature findings. Procedia - Social and Behavioral Sciences, 24, 1302-1310.

VakilAlroaia, Y., \& Nabavi, S.R., \& Eslami Mofidabadi, H. (2012). Surveying effects of forwardbackward $\mathrm{P} / \mathrm{E}$ ratios on stock's return and fluctuation in Tehran's stock exchange. Management Science Letters, 2(7), 1731-1740. 